\title{
Characterization and multivariate classification of grapes and wines of two Cabernet Sauvignon clones
}

\author{
Vívian Maria Burin(1), Aparecido Lima da Silva(2), Luciane Isabel Malinovski(2), Jean Pierre Rosier(3), \\ Leila Denise Falcão(4) and Marilde Teresinha Bordignon-Luiz ${ }^{(1)}$
}

\begin{abstract}
(1) Universidade Federal de Santa Catarina (UFSC), Departamento de Ciência e Tecnologia de Alimentos, Rodovia Admar Gonzaga, no 1.346, CEP 88034-001 Florianópolis, SC, Brazil. E-mail: viburin@gmail.com, bordign@cca.ufsc.br (2)UFSC, Departamento de Fitotecnia. E-mail: alsilva@cca.ufsc.br, lucianeisabel@yahoo.com.br ${ }^{(3)}$ Empresa de Pesquisa Agropecuária e Extensão Rural de Santa Catarina, Estação Experimental de Videira, Caixa Postal 21, CEP 89560-000 Videira, SC, Brazil. E-mail: rosier@formatto.com.br (4)Laboratoires Dubernet Oenologie, Rue de la Combe du Meunier, no 35, 11.100, Montredon-Corbières, France. E-mail: leiladfalcao@yahoo.com.br
\end{abstract}

\begin{abstract}
The objective of this work was to assess and characterize two clones, 169 and 685, of Cabernet Sauvignon grapes and to evaluate the wine produced from these grapes. The experiment was carried out in São Joaquim, SC, Brazil, during the 2009 harvest season. During grape ripening, the evolution of physical-chemical properties, phenolic compounds, organic acids, and anthocyanins was evaluated. During grape harvest, yield components were determined for each clone. Individual and total phenolics, individual and total anthocyanins, and antioxidant activity were evaluated for wine. The clones were also assessed regarding the duration of their phenological cycle. During ripening, the evolution of phenolic compounds and of physical-chemical parameters was similar for both clones; however, during harvest, significant differences were observed regarding yield, number of bunches per plant and berries per bunch, leaf area, and organic acid, polyphenol, and anthocyanin content. The wines produced from these clones showed significant differences regarding chemical composition. The clones showed similar phenological cycle and responses to bioclimatic parameters. Principal component analysis shows that clone 685 is strongly correlated with color characteristics, mainly monomeric anthocyanins, while clone 169 is correlated with individual phenolic compounds.
\end{abstract}

Index terms: Vitis vinifera, phenolic compounds, phenology, ripeness.

\section{Caracterização e classificação multivariada de uva e vinho de dois clones de Cabernet Sauvignon}

Resumo - O objetivo deste trabalho foi avaliar e caracterizar dois clones, 169 e 685, de uvas Cabernet Sauvignon, e avaliar os vinhos produzidos com estas uvas. O experimento foi realizado em São Joaquim, SC, durante a safra de 2009. No período de maturação, foi avaliada a evolução da composição físico-química, dos compostos fenólicos, dos ácidos orgânicos e das antocianinas. Na colheita das uvas, foram determinados os componentes de produtividade para cada clone. Os vinhos foram analisados quanto aos fenólicos individuais e totais, às antocianinas individuais e totais, e à atividade antioxidante. Os clones também foram avaliados quanto a seus ciclos fenológicos. Durante o período de maturação, a evolução dos compostos fenólicos e dos parâmetros físico-químicos foi similar para os dois clones; no entanto, no período da colheita, foram observadas diferenças significativas em relação à produtividade, ao número de cachos por planta e de bagas por cacho, à área foliar e ao conteúdo de ácidos orgânicos, de polifenóis e de antocianinas. Os vinhos produzidos com estes clones mostraram diferença significativa quanto à composição química. Os clones apresentaram duração do ciclo fenológico e parâmetros bioclimáticos similares. A análise de componentes principais indica que o clone 685 é fortemente correlacionado às características de cor, principalmente às antocianinas monoméricas, enquanto o clone 169 é correlacionado aos compostos fenólicos individuais.

Termos para indexação: Vitis vinifera, compostos fenólicos, fenologia, maturação.

\section{Introduction}

Clonal selection has led to considerable improvements in viticulture, particularly in terms of grape quality and quantity. For Vitis vinifera L., clones are selected mostly for genetic resistance to pests and diseases, and for specific chemical characteristics. Phenotypic variations are often observed among clones of the same variety, and can appear before or after berry ripening (Zamuz et al., 2007).

In viticulture, phenology is used to characterize varieties and clones within the same variety, since phenological periods vary according to genotype, climatic conditions, and geographic location (Jones \& Davis, 2000). 
The quality of grapes at harvest is the main factor that influences wine quality. Grape ripening begins with color change and ends at harvest. Studies indicate that different clones of the same variety also show significant differences regarding chemical composition of their grapes. Some clones have the capacity to produce wine with distinct color, aromatic profile, and phenolic content (Santesteban \& Royo, 2006).

The objective of this work was to assess and characterize two clones, 169 and 685, of Cabernet Sauvignon grapes, cultivated in São Joaquim, SC, Brazil, during the 2009 harvest season, and to evaluate the wine produced from these grapes.

\section{Materials and Methods}

The experiment was carried out at a commercial vineyard located at São Joaquim, SC, Brazil ( $28^{\circ} 15^{\prime} 12^{\prime \prime} \mathrm{S}$ and $49^{\circ} 34^{\prime} 51^{\prime \prime} \mathrm{W}$, at 1,200-m altitude). The soil of the region is classified as Humic Dystrudept (Cambissolo Húmico alumínico) and is well drained, with medium clay texture, soft friable consistency, high water retention capacity, and absence of stones (Falcão et al., 2008). Meteorological data were obtained from a meteorological station belonging to Centro de Informações de Recursos Ambientais e de Hidrometeorologia de Santa Catarina from Empresa de Pesquisa Agropecuária e Extensão Rural de Santa Catarina (Epagri), located at 1,000 $\mathrm{m}$ above sea level and $500 \mathrm{~m}$ from the vineyard.

Two clones, 169 and 685, of Cabernet Sauvignon grapes were evaluated in the 2009 harvest season. The training system used for both clones was the V system, and the rootstock used was 'Paulsen 1103' (Vitis berlandieri Planch x Vitis rupestris Scheele). A random experimental design was used. For all plants, row and vine spacing were 3.0 and $1.5 \mathrm{~m}$, respectively. Twelve plants from each clone were randomly marked in four central rows. The data collected included daily observations of maximum $\left(\mathrm{T}_{\max }\right)$, minimum $\left(\mathrm{T}_{\text {min }}\right)$ and average $\left(\mathrm{T}_{\text {avg }}\right)$ temperatures, rainfall $(\mathrm{mm})$, and air relative humidity $(\%)$. These general climatic parameters were used to derive other variables used in viticulture studies, such as thermal amplitude (cumulative difference of daily air temperature, i.e., $\mathrm{T}_{\max }-\mathrm{T}_{\min }$ ); heat summation requirements, observed for growing degree-days (GDD) based on $10^{\circ} \mathrm{C}$ :

$$
\left[\mathrm{GDD}=\Sigma\left(\mathrm{T}>10^{\circ} \mathrm{C}-10^{\circ} \mathrm{C}\right)\right],
$$

from Winkler, 1980; and heliothermal index (HI), determined according to Huglin (1978), in which $\mathrm{Tb}=10^{\circ} \mathrm{C}\left(\mathrm{HI}=\Sigma\left\{\left[\left(\mathrm{T}_{\text {avg }}-\mathrm{T}_{\mathrm{b}}\right)+\left(\mathrm{T}_{\max }-\mathrm{T}_{\mathrm{b}}\right)\right] / 2\right\}\right)$.

Data on budburst, blooming, setting, veraison, and harvest dates for Cabernet Sauvignon vine clones were also evaluated. Budburst, blooming, setting and veraison events are considered to occur when, for a given varietal, $50 \%$ of the plants show physiological response. Harvest data was collected, on the same day, at approximately $23^{\circ} \mathrm{Brix}$, which is related to optimal sugar levels, for both clones.

The following yield components were evaluated: number of bunches per plant, berry weight $(n=100)$, bunch weight $(\mathrm{n}=10)$, and number of berries per bunch $(\mathrm{n}=10)$. All parameters were measured at harvest and were used to calculate yield per plant $(\mathrm{kg})$. Plant leaf area (LA) was calculated as the sum of the area of all the leaves of each plant. Individual LA was estimated by nondestructive measuring of the length of the secondary nerves, according to the procedure described by Carbonneau (1976), taking into account the close relationship with the sum of the length of secondary nerves,

$\mathrm{LA}\left(\mathrm{cm}^{2}\right)=-127.13+16.056 \mathrm{SN} ; \mathrm{R}^{2}=0.9582 ; \mathrm{p}<0.001$,

in which: SN is the sum of the length of secondary nerves. To establish this relationship, the area $\left(\mathrm{cm}^{2}\right)$ of 150 leaves from each clone was measured using an image analysis system AM 300 (ADC, Hoddesdon, United Kingdom).

The monitoring of grape ripening began at veraison, when approximately $50 \%$ of the berries had turned red. The samples were collected at ten-day intervals. Each sample consisted of a total of 240 berries (eight berries per vine) for each clone. For ripening analyses, juice was squeezed from 30 fresh randomly selected berries, in triplicate. The samples were analyzed according to Office International de la Vigne et du Vin (1990) procedures for $\mathrm{pH}$, titratable acidity (TA, mg tartaric acid $100 \mathrm{~g}^{-1}$ grape skin), and total soluble solids (TSS, ${ }^{\circ}$ Brix). The maturation index (MI) was obtained from the TSS/TA ratio. Total phenolics (TP, mg gallic acid $100 \mathrm{~g}^{-1}$ grape skin) (Singleton \& Rossi, 1965) and total monomeric anthocyanins (TMA, mg malvidin 3-glucoside $100 \mathrm{~g}^{-1}$ grape skin) (Giusti \& Wrolstad, 2001) 
were determined by extract from grape skins (90 berries) macerated overnight in methanol: $\mathrm{HCl}$ (99:1). Organic acid determination (tartaric, malic, citric, succinic, and lactic acid) was carried out using a Shimadzu liquid chromatograph (Shimadzu Corporation, Kyoto, Japan); the column $(4.6 \times 250 \mathrm{~mm}$, $5 \mu \mathrm{m}$ particle size) and guard column $(4.6 \times 12.5 \mathrm{~mm})$ were C18 reversed-phase (Hichrom, Berkshire, United Kingdom). For the analyses, grape juice was squeezed from 30 randomly selected fresh berries, in triplicate, and then centrifuged at 3,000 rpm for $15 \mathrm{~min}$, diluted in Milli-Q purified water by a factor of 10 , filtered through a $0.45 \mu \mathrm{m}$ PTFE membrane (Millipore), and injected into a high pressure liquid chromatograph (HPLC). The analyses were carried out using external standardization, with isocratic elution and detection at $212 \mathrm{~nm}$ (Escobal et al., 1998).

Wines from each Cabernet Sauvignon clone were produced under the same microvinification conditions at Epagri's Estação Experimental de Videira, Videira, $\mathrm{SC}$, Brazil. Wines were analyzed between six and eight months after microvinification. They were assessed for total polyphenols (TP, mg L${ }^{-1}$ gallic acid) (Singleton \& Rossi Junior, 1965). 1,1-diphenyl-2-picrylhydrazyl (DPPH) radical activity was measured by the extinction of the maximum absorption at $517 \mathrm{~nm}$ (Kim etal., 2002), and TMA was determined by the $\mathrm{pH}$ difference method (Giusti \& Wrolstad, 2001). Anthocyanin analyses (malvidin, peonidin, and delphinidin-3-glucoside) were carried out using a Shimadzu liquid chromatograph, (Shimadzu Corporation, Kyoto, Japan) according to García-Falcón et al. (2007). Phenolic content (catechin, quercetin, trans-resveratrol, gallic acid, ferulic acid, p-coumaric acid, and caffeic acid) was analyzed with a method validated in the laboratory, by internal standardization $\left(16.2 \mathrm{mg} \mathrm{L}^{-1}\right.$ of morin solution). The mobile phase consisted of acetic acid in filtered Milli-Q water ( $\mathrm{pH}$ 2.6) as solvent A, and 20\% of solution $\mathrm{A}$ in acetonitrile as solvent $\mathrm{B}$. Elution was done using a linear gradient: $0-30 \%$ of solvent $\mathrm{B}$ for 35 $\min , 30-50 \%$ for $5 \mathrm{~min}$, and $50-100 \%$ for $15 \mathrm{~min}$. The flow rate was $1.2 \mathrm{~mL} \mathrm{~min}^{-1}$.

All analyses were carried out with two replicates, in triplicate. Linear regression; analysis of variance; principal component analysis (PCA); and Tukey's HSD test at $5 \%$ probability were performed using the software Statistica 6 (Statsoft, 2001).

Pesq. agropec. bras., Brasília, v.46, n.5, p.474-481, maio 2011

\section{Results and Discussion}

The average temperature during grape ripening ranged from 11.9 to $20.5^{\circ} \mathrm{C}$. The occurrence of cold nights, characteristic of São Joaquim, SC, Brazil, favored the accumulation of sugars and phenolic compounds, especially anthocyanins. The highest temperature was observed $\left(15.2^{\circ} \mathrm{C}\right)$ from veraison until harvest, which is considered an important factor for plant physiology, since it influences photosynthesis/respiration balance and, consequently, the accumulation of energy for grape development during this period (González-Neves et al., 2007). Air relative humidity during the phenological
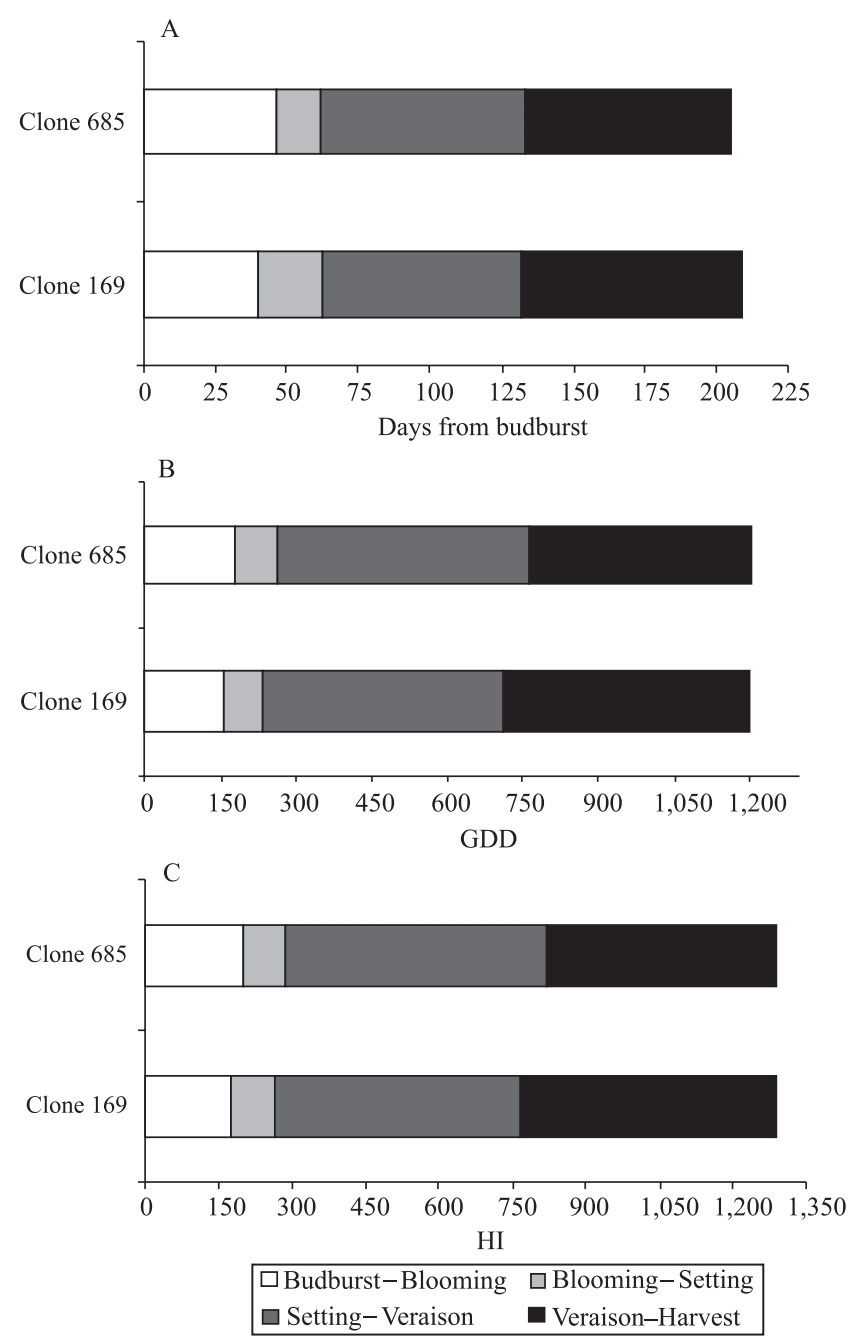

Figure 1. Number of days of total phenological cycle (A), heat summation requirements (GDD, growing degree-days based on $\left.10^{\circ} \mathrm{C}\right)(\mathrm{B})$, and heliothermal index (HI) (C) for the main phenological periods (budburst-harvest) of clones 169 and 685 of Cabernet Sauvignon grapes. 
cycle was above $87 \%$, which is typical of southern Brazil and suitable for berry development (Esteban et al., 2002). Total rainfall for the cycle evaluated was around $900 \mathrm{~mm}$. Falcão et al. (2008), in studies carried out in the same location, in 2005 and 2006, with Cabernet Sauvignon grapes, found rainfall values of 900 and $600 \mathrm{~mm}$, respectively.

Little difference was observed in the duration of the phenological phases for both clones (Figure 1). Clone 169 had a cycle of 209 days, and clone 685 of 205 days. Regina \& Audeguin (2005) evaluated three clones of the Syrah variety and found a four-day difference for the entire phenological cycle. However, a greater difference was observed in this study between the blooming and setting periods: the duration for clone 169 was 23 days longer. Ewart et al. (1993), while assessing Sauvignon Blanc clones in the same year, observed small and insignificant differences from veraison to harvest.

The Winkler index (GDD) and Hunglin's HI are widely used to determine the thermal units necessary for the vine to complete the different phases of the phenological cycle, mainly as a guide for the selection of different clones of the same variety, and as a tool to indicate the region's potential for growing quality grapes. In terms of Winkler regions, São Joaquim, $\mathrm{SC}$, Brazil, is classified as 'Region I' ( $<1,389$ GDD), i.e., a "cold region" (Figure 1), taking into account the summed GDD results for the phenological cycle (budburst to harvest) of both clones (approximately 1,200 GDD). These results are in agreement with those found by Falcão et al. (2010) and Gris et al. (2010), who also evaluated different varieties in this location. For the $\mathrm{HI}$, the region is classified as $\mathrm{HI}_{1}$, also considered cold $(\leq 1,500)$, according to the geoviticulture multicriteria climatic classification system (Tonietto \& Carbonneau, 2004). There was no significant difference between clones 169 and 685 regarding heat summation requirements. Fallahi et al. (2005), while assessing different clones, observed no significant difference between total thermal requirements for clones of Cabernet Sauvignon grapes, in the same harvest.

The determination of LA provides information on the relationship between plant photosynthesis and yield and fruit quality. The clones showed significant difference $(\mathrm{p}<0.05)$ for this character (Table 1). Clone $685 \mathrm{had}$ higher LA per plant than clone 169, and showed higher results regarding yield components, which is in agreement with Santesteban \& Royo (2006), who reported that LA is related to plant vigor.

Clone 685 showed higher yield $(\mathrm{p}<0.05)$ than clone 169, with more bunches per plant, higher bunch weight, and more berries per bunch. These differences are directly related to the rainfall amounts during veraison, while yield is positively related to the duration of the phenological cycle. According to Mota et al. (2009), rootstock significantly influences yield. However, in this study, since the clones came from the same location and rootstock, and the harvest period and phenology were similar, the differences observed can be attributed exclusively to the genetic characteristics of each clone. These results are similar to those obtained by Wolpert et al. (1995), when evaluating seven Cabernet Sauvignon clones from California. The authors found significant differences regarding yield, and bunch and berry weights. These results agree with those reported by Alonso et al. (2004), who observed variability between clones of the Albariño variety grown in Spain.

The evolution of TSS for the two clones was very similar (Figure 2), with a progressive increase until the end of the ripening period, reaching ${ }^{\circ}$ Brix values of 23.5 and 24.0 for clones 169 and 685, respectively. The $\mathrm{pH}$ values increased up to 50 days from veraison, and then decreased until the end of the ripening period, reaching values of 3.51 and 3.49 for clones 169 and 685 , respectively; no significant differences $(\mathrm{p}<0.05)$ were observed. A significant correlation $(\mathrm{p}<0.05)$ was obtained between $\mathrm{pH}$ decrease and acidity increase for clones $169(\mathrm{r}=0.88)$ and $685(\mathrm{r}=0.86)$. The MI, which indicates sugar-acid balance in grapes,

Table 1. Physical characteristics of clones 169 and 685 of Cabernet Sauvignon grapes.

\begin{tabular}{lcc}
\hline Character $^{(1)}$ & Clone 169 & Clone 685 \\
\hline Branch number & $15 \mathrm{~b}$ & $23 \mathrm{a}$ \\
Leaves per branch & $21 \mathrm{~b}$ & $16 \mathrm{a}$ \\
Branch length $(\mathrm{m})$ & $1.4 \mathrm{~b}$ & $1.5 \mathrm{a}$ \\
Plant yield $(\mathrm{kg})$ & $2.2 \mathrm{~b}$ & $4.1 \mathrm{a}$ \\
Bunches per plant & $20.6 \mathrm{~b}$ & $31.2 \mathrm{a}$ \\
Bunch weight $(\mathrm{g})(\mathrm{n}=5)$ & $113.9 \mathrm{~b}$ & $146.8 \mathrm{a}$ \\
Berries per bunch $(\mathrm{n}=5)$ & $85 \mathrm{~b}$ & $96 \mathrm{a}$ \\
Berry weight $(\mathrm{g})(\mathrm{n}=100)$ & $1.2 \mathrm{~b}$ & $1.3 \mathrm{a}$ \\
Seed weight $(\mathrm{g})(\mathrm{n}=50)$ & $2.1 \mathrm{~b}$ & $2.2 \mathrm{a}$ \\
Seeds per berry $(\mathrm{n}=50)$ & $1.3 \mathrm{a}$ & $1.3 \mathrm{a}$ \\
Leaf area per plant $\left(\mathrm{m}^{2}\right)$ & $4.1 \mathrm{~b}$ & $6.3 \mathrm{a}$ \\
\hline
\end{tabular}

${ }^{(1)}$ Means followed by equal letters, in the lines, do not differ by Tukey's HSD test at $5 \%$ probability. 
increased progressively during ripening, with end values at harvest of 31.3 and 39.3 for clones 169 and 685 , respectively.

There was significant difference $(\mathrm{p}<0.05)$ for TMA content, which increased during ripening of both clones; clone 685 had the highest concentration at
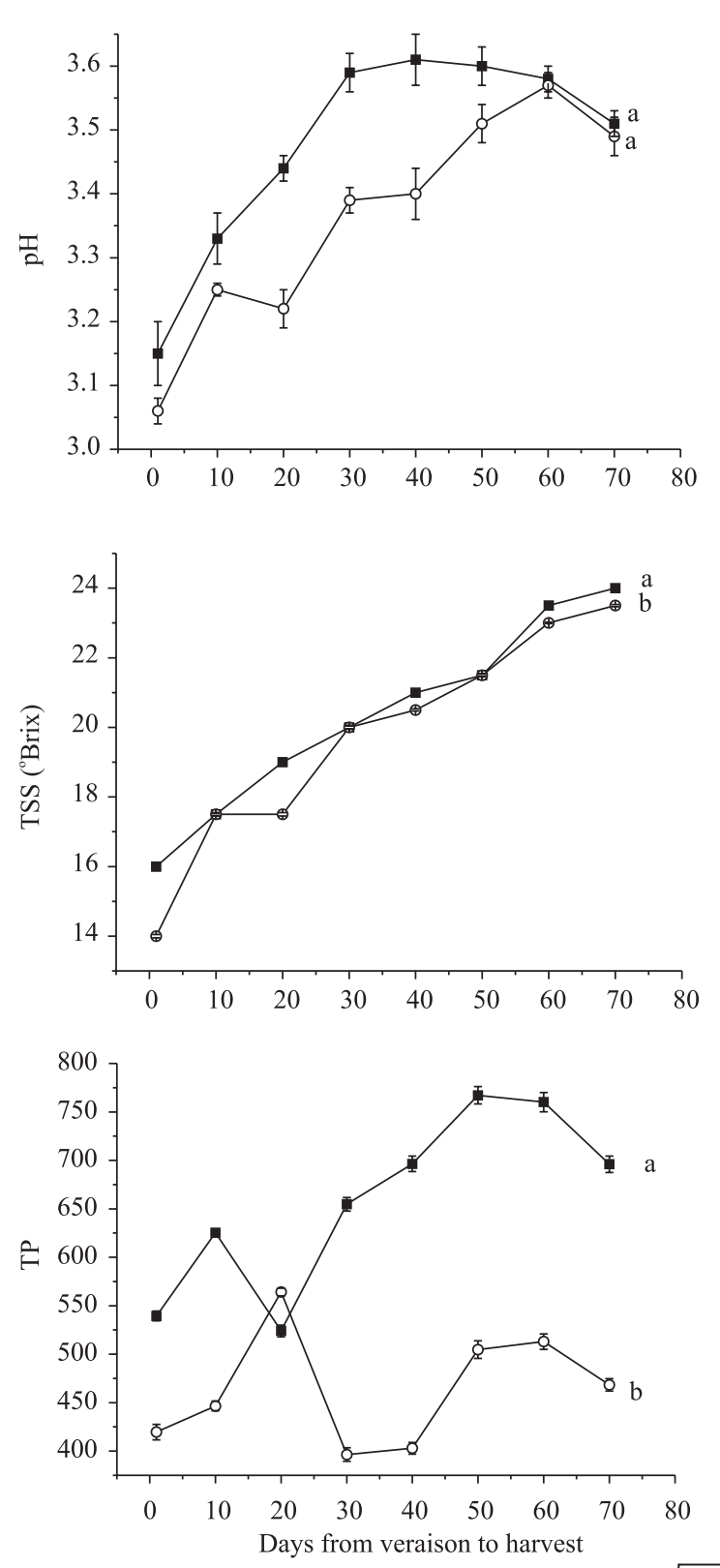

$\rightarrow-$ Clone 169 -0- Clone 685 harvest (411.5 mg 100g-1 skin). A significant difference $(p<0.05)$ was also observed between the two clones regarding TP concentration; clone 169 had the highest concentration (685.9 mg $100 \mathrm{~g}^{-1}$ skin). According to Mori et al. (2005), the accumulation of phenolic compounds in grape berries is favored mainly by low
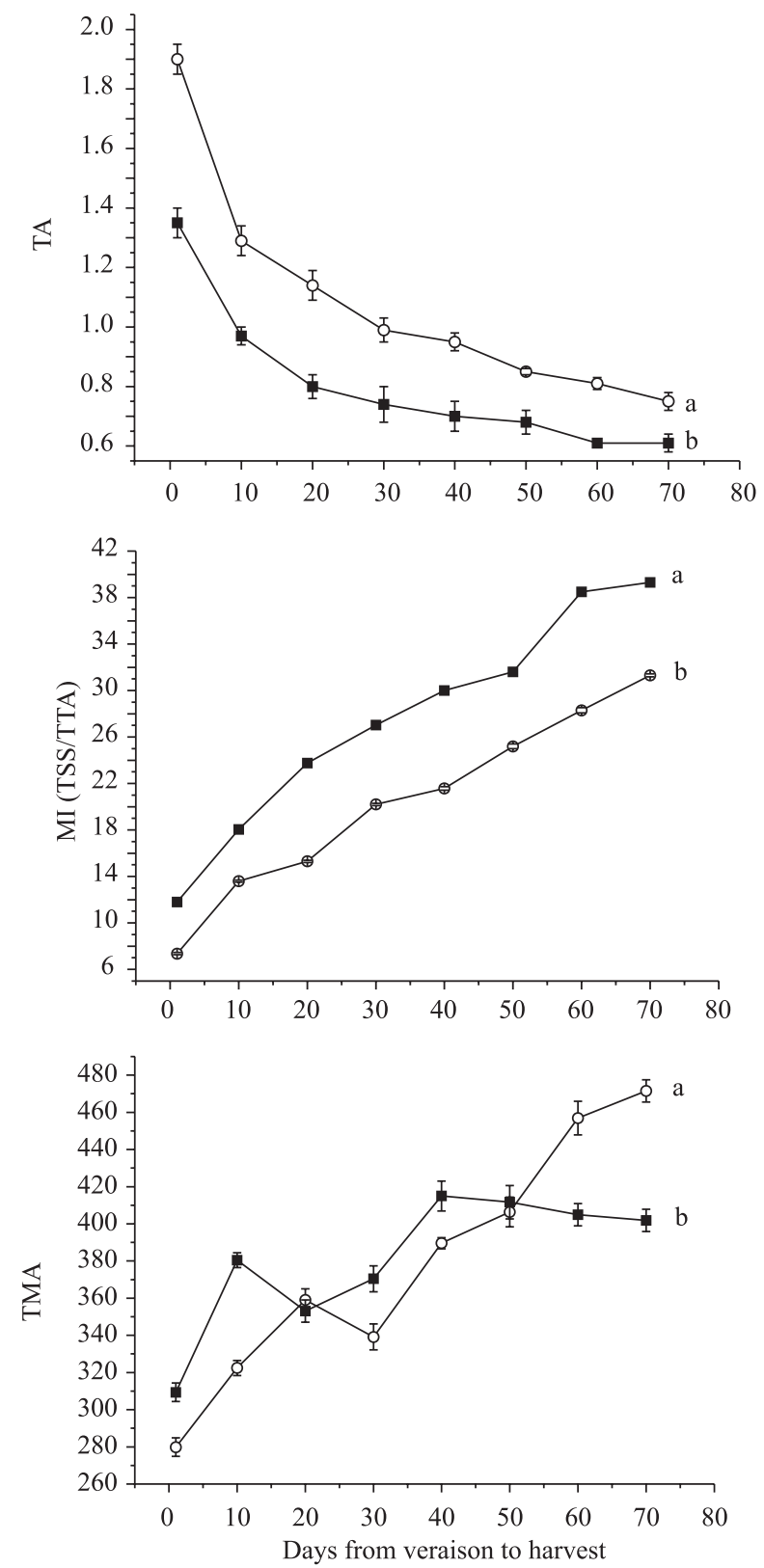

Figure 2. $\mathrm{pH}$; TA, titratable acidity $\mathrm{mg}$ tartaric acid $100 \mathrm{~mL}^{-1}$ juice; TSS, total soluble solids ${ }^{\circ} \mathrm{Brix}$; MI, maturation index; $\mathrm{TP}$, total phenolics mg gallic acid $100 \mathrm{~g}^{-1}$ fresh grape skin; and TMA, total monomeric anthocyanins mg malvidin 3-glucoside $100 \mathrm{~g}^{-1}$ fresh grape skin; from veraison to harvest of Cabernet Sauvignon clones 169 and 684 grapes. Means \pm SD followed by equal letters do not differ by Tukey' HSD test at 5\% probability. 
temperatures during ripening, which was evidenced in São Joaquim, SC, Brazil, and could explain the high phenolic concentration. However, since both clones were evaluated in the same vineyard and vintage, and were influenced by the same temperatures, the differences observed in TP and TMA content may indicate different characteristics regarding the phenolic content of each clone. A significant correlation was observed $(\mathrm{p}<0.05)$ between TMA and clone 685 $(\mathrm{R}>0.9)$; clone 169 showed a higher correlation with TP content $(\mathrm{R}>0.9)$, which indicates that the phenolic data obtained during ripening can be used as a tool to differentiate between these clones.

For the two clones, malic acid predominates in the early ripening stage (Figure 3), which is intensely
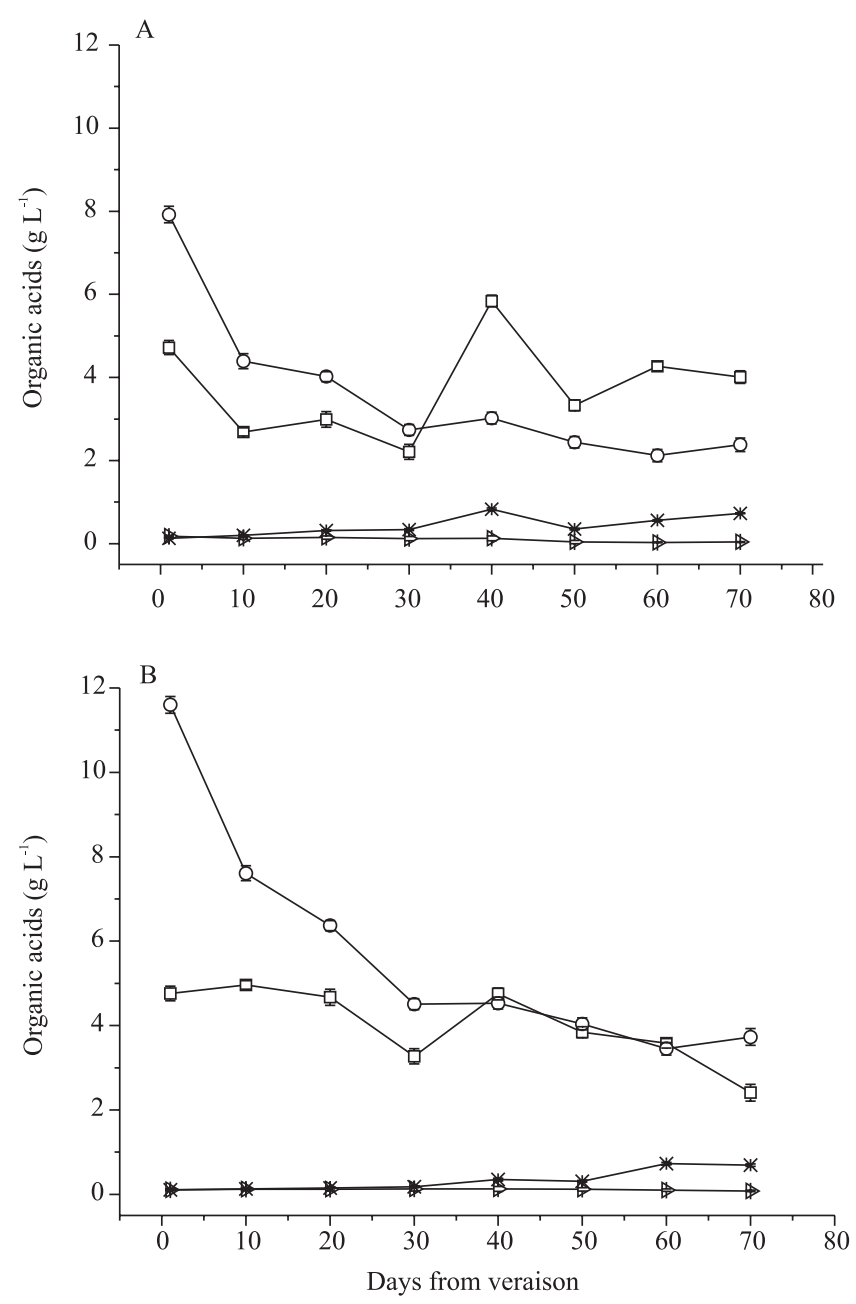

$\neg \square$ Tartaric acid $\rightarrow-$ Malic acid $\rightarrow \subset$ Citric acid $\rightarrow$ Succinic acid

Figure 3. Evolution of organic acids from veraison to harvest of clone 169 (A) and clone 685 (B) of Cabernet Sauvignon grapes. synthesized during the budburst and setting periods; however, its concentration decreases during ripening, due to the predominance of degradation reactions. A decrease in tartaric acid was also observed during ripening. The presence of lactic acid was not detected in any grape sample. At harvest, grapes showed predominance of different acids in must, with the highest concentration of malic acid for clone 685 and of tartaric acid for clone 169. This difference can be attributed to the larger LA of clone 685, since malic acid is mostly synthesized in leaves.

Zamuz et al. (2007), who analyzed different clones of the Albariño variety from the same location and harvest, found similar results. The authors observed a significant difference among clones regarding physical-chemical parameters in must, at harvest, which indicates that classical parameters could be used to differentiate between clones of the same grape variety. Ferrandino \& Guidoni (2010), while evaluating different clones of the Barbera variety grown in the same location and in the same and different harvests, also found that ripening data on $\mathrm{pH}$, soluble solids, and total acidity showed significant differences between clones.

Flavonoid and nonflavonoid phenolic compounds (Table 2) represent the main polyphenols in red wines, and are widely used to differentiate between wines produced from different grape varieties. However, few studies use the main phenolic compounds to differentiate wines produced with different clones of the same variety. Wines from clone 169 showed the highest concentrations

Table 2. Phenolic composition $\left(\mathrm{mg} \mathrm{L}^{-1}\right)$, color parameters $\left(\mathrm{mg} \mathrm{L}^{-1}\right)$, and antioxidant activity $\left(\mathrm{mmol} \mathrm{L}^{-1}\right)$ of wines $(\mathrm{W})$ from clones 169 and 685 .

\begin{tabular}{lcc}
\hline Chemical parameter $^{(1)}$ & $\mathrm{W}-169$ & $\mathrm{~W}-685$ \\
\hline Total phenolics & $2,389.3 \pm 4.2 \mathrm{~b}$ & $1,884.2 \pm 4.9 \mathrm{a}$ \\
Total monomeric anthocyanins & $260.5 \pm 2.4 \mathrm{~b}$ & $332.9 \pm 2.5 \mathrm{a}$ \\
Malvidin-3-glucoside & $67.32 \pm 0.61 \mathrm{~b}$ & $85.91 \pm 0.15 \mathrm{a}$ \\
Delphinidin-3-glucoside & $19.38 \pm 0.03 \mathrm{~b}$ & $24.78 \pm 0.0 \mathrm{a} 8$ \\
Peonidin-3-glucoside & $21.07 \pm 0.18 \mathrm{~b}$ & $32.54 \pm 0.20 \mathrm{a}$ \\
Catechin & $49.35 \pm 0.85 \mathrm{~b}$ & $14.51 \pm 0.12 \mathrm{a}$ \\
Quercetin & $23.18 \pm 0.96 \mathrm{~b}$ & $14.80 \pm 1.11 \mathrm{a}$ \\
Trans-resveratrol & $1.52 \pm 0.04 \mathrm{~b}$ & $0.75 \pm 0.02 \mathrm{a}$ \\
Gallic acid & $23.31 \pm 0.71 \mathrm{~b}$ & $13.20 \pm 0.06 \mathrm{a}$ \\
Caffeic acid & $2.01 \pm 0.38 \mathrm{~b}$ & $1.56 \pm 0.09 \mathrm{a}$ \\
Ferulic acid & $0.68 \pm 0.01 \mathrm{~b}$ & $0.37 \pm 0.01 \mathrm{a}$ \\
p-coumaric acid & $1.69 \pm 0.03 \mathrm{~b}$ & $0.47 \pm 0.04 \mathrm{a}$ \\
1,1-diphenyl-2-picrylhydrazyl & $20.8 \mathrm{~b} \pm 0.1 \mathrm{~b}$ & $16.1 \pm 0.1 \mathrm{a}$ \\
\hline
\end{tabular}

${ }^{(1)}$ Means \pm SD followed by equal letters, in the lines, do not differ by Tukey's HSD test at $5 \%$ probability. 


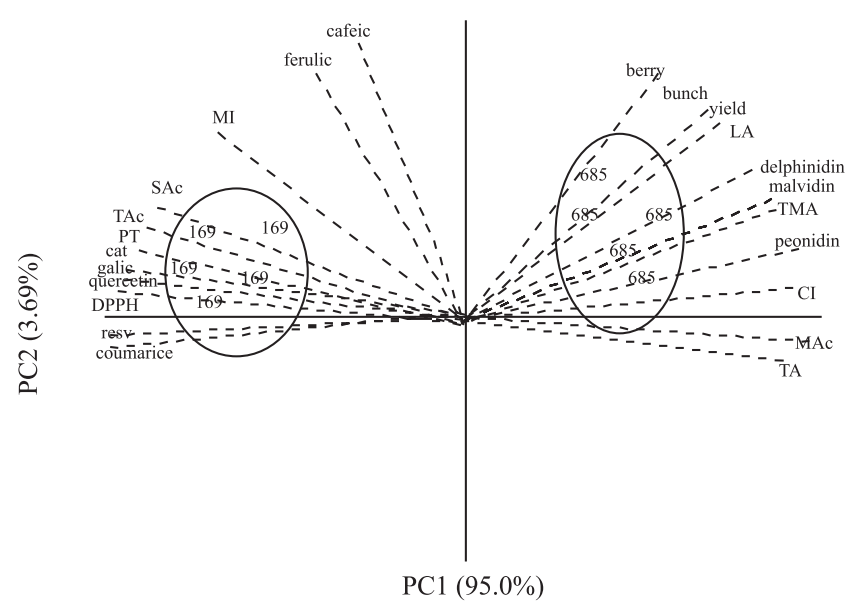

Figure 4. Principal components analysis (PCA) of the significant results from clones 169 and 685 of Cabernet Sauvignon grape compositions at harvest, and in wines made from these clones. DPPH, 1,1-diphenyl-2-picrylhydrazyl; MI, maturation index; LA, leaf area; TMA, total monomeric anthocyanins; TA, titratable acidity.

of all individual phenolics determined by HPLC, of which catechin was predominant. This clone also showed the highest antioxidant activity. Wines produced from clone 685 showed the highest concentrations of monomeric anthocyanins, especially malvidin 3-glucoside. Forveille et al. (1996) demonstrated that clones differ regarding anthocyanin composition.

Principal component analysis (PCA) was carried out with the data on grape composition at harvest, yield components, LA, and chemical composition of wines produced from the clones (Figure 4); all results showed significant difference $(\mathrm{p}<0.05)$. PC1 x PC2 explained $98.69 \%$ of the total variability. The first component represented $95 \%$ of the total variability and could be considered a "clone", since both clones were distributed along PC1, showing a clear separation of the grape and wine samples according to the clone. Clone 685 showed a strong positive correlation with color parameters, such as TMA, malvidin, delphinidin and peonidin 3-glucoside, as well as with yield components and LA. Clone 169 was strongly positively correlated with individual phenolic compounds determined by HPLC, total polyphenols, and DPPH. These results agree with those observed in other studies, which indicate that it is possible to differentiate between clones of the same grape variety with principal component analysis (Zamuz et al., 2007; Ferrandino \& Guidone, 2010).

\section{Conclusions}

1. Clones 169 and 685 of Cabernet Sauvignon grapes show similar performance regarding the phenological cycle and the evolution of the compounds during ripening.

2. There are significant differences between the clones in terms of chemical composition of grapes and yield components of vines. Clone 685 has higher productivity, higher bunch weight, more bunches per plant, and more berries per bunch.

3. The wines produced with clones 169 and 685 show the same chemical characteristics as their grapes.

4. Clone 685 is strongly correlated with individual monomeric anthocyanins, while clone 169 shows a higher correlation with total and individual phenolic compounds and antioxidant activity.

5. Differences between clones 169 and 685 are exclusively attributed to their chemical composition and physical characteristics, which are potential tools for the characterization and differentiation of different clones from the same grape variety.

\section{References}

ALONSO, S.B.; BLANCO, J.L.S.; RODIGUEZ, M.C.M. Intravarietal agronomic variability in Vitis vinifera L. cv. Albariño. American Journal of Enology and Viticulture, v.55, p.279-282, 2004.

CARBONNEAU, A. Analise de la croissance des feuilles du sarment de vigne: estimation de la surface foliare par enchantillonnage. Connaissance Vigne Vin, v.10, p.141-159, 1976.

ESCOBAL, A.; IRIONDO, C.; LABORRA, C.; ELEJALDE, E.; GONZALEZ, I. Determination of acids and volatile compounds in red Txakoli wine by high-performance liquid chromatography and gas chromatography. Journal of Chromatography A, v.823, p.349-354, 1998.

ESTEBAN, M.A.; VILLANUEVA, M.J.; LISSARRAGUE, J.R. Relationships between different berry components in Tempranillo (Vitis vinifera L.) grapes from irrigated and non-irrigated vines during ripening. Journal of the Science of Food and Agriculture, v.82, p.1136-1146, 2002.

EWART,A.J.W.;GAWEL,R.;THISTLEWOOD,S.P.;MCCARTHY, M.G. Evaluation of must composition and wine quality of six clones of Vitis vinifera cv. Sauvignon Blanc. Australian Journal of Experimental Agriculture, v.33, p.945-951, 1993.

FALCÃO, L.D.; BURIN, V.M.; CHAVES, E.S.; VIEIRA, H.J.; BRIGHENTI, E.; ROSIER, J.P.; BORDIGNON-LUIZ, M.T. Vineyard altitude and mesoclimate influences on the phenology and maturation of Cabernet Sauvignon grapes from Santa Catarina State. Journal International des Sciences de la Vigne et du Vin, v.44, p.135-150, 2010. 
FALCÃO, L.D.; CHAVES, E.S.; BURIN, V.M.; FALCÃO, A.P.; GRIS, E.F.; BONIN, V.; BORDIGNON-LUIZ, M.T. Ripening of Cabernet Sauvignon berries from grapevines grown with two different training systems and environmental conditions in a new grape growing region in Brazil. Ciencia e Investigación Agraria, v.35, p.321-332, 2008.

FALLAHI, E.; FALLAHI, B.; SHAFII, B.; STARK, J.C. Performance of six wine grapes under Southwest Idaho environmental conditions. Small Fruits Review, v.4, p.77-84, 2005.

FERRANDINO, A.; GUIDONI, S. Anthocyanins, flavonols and hydroxycinnamates: an attempt to use them to discriminate Vitis vinifera L. cv 'Barbera' clones. European Food Research and Technology, v.230, p.417-427, 2010.

FORVEILLE，L.; VERCAUTEREN，J.; RUTLEDGE，D.N. Multivariate statistical analysis of two-dimensional NMR data to differentiate grapevine cultivars and clones. Food Chemistry, v.57, p.441-450, 1996.

GARCÍA-FALCÓN, M.S.; PÉREZ-LAMELA, C.; MARTÍNEZ-CARBALHO, E.; SIMAL-GÁNDARA, J. Determination of phenolic compounds in wines: influence of bottle storage of young red wines on their evolution. Food Chemistry, v.105, p.248-259, 2007.

GIUSTI, M.M.; WROLSTAD, R.E. Characterization and measurement of anthocyanins by UV-visible spectroscopy. In: WROLSTAD, R.E. (Ed.). Current protocols in food analytical chemistry. New York: John Wiley and Sons, 2001. F1.2-1.2.13.

GONZÁLEZ-NEVES, G.; FRANCO, J.; BARREIRO, L.; GIL, G.; MOUTOUNET, M.; CARBONNEAU, A. Varietal differentiation of Tannat, Cabernet-Sauvignon and Merlot grapes and wines according to their anthocyanic composition. European Food Research and Technology, v.225, p.111-117, 2007.

GRIS, E.F.; BURIN, V.M.; BRIGHENTI, E.; VIEIRA, H.; BORDIGNON-LUIZ, M.T. Phenology and ripening of Vitis vinifera grape varieties in São Joaquim, southern Brazil: a new South American wine growing region. Ciencia e Investigación Agraria, v.37, p.61-75, 2010.

HUGLIN, P. Nouveau mode d'évaluation des possibilités héliothermiques d'un milieu viticole. In: SYMPOSIUM INTERNATIONAL SUR L'ÉCOLOGIE DE LA VIGNE, L., Constança, Roumanie, 1978. Annales. Constança: Ministère de l'Agriculture et de l'Industrie Alimentaire, 1978. p.89-98.

JONES, G.V.; DAVIS, R.E. Climate influences on grapevine phenology, grape composition, and wine production and quality for
Bordeaux, France. American Journal of Enology and Viticulture, v.51, p.249-261, 2000

KIM, Y.K.; GUO, Q.; PACKER, L. Free radical scavenging activity of red ginseng aqueous extracts. Toxicology, v.172, p.149-156, 2002.

MORI, K.; SUGAYA, S.; GEMMA, H. Decreased anthocyanin biosynthesis in grape berries grown under elevated night temperature condition. Scientia Horticulturae, v.105, p.319-330, 2005.

MOTA, R.V. da; SOUZA, C.R. de; FAVERO, A.C.; SILVA, C.P.C. e; CARMO, E.L.; FONSECA, A.R.; REGINA, M. de A. Produtividade e composição físico-química de bagas de cultivares de uva em distintos porta-enxertos. Pesquisa Agropecuária Brasileira, v.44, p.576-582, 2009.

OFFICE INTERNATIONAL DE LA VIGNE ET DU VIN. Recueil des methodes internationales d'analyse des vins et des mouts. Paris: OIV, 1990.

REGINA, M. de A.; AUDEGUIN, L. Avaliação ecofisiológica de clones de videira cv. Syrah. Ciência e Agrotecnologia, v.29, p.875-879, 2005.

SANTESTEBAN, L.G.; ROYO, J.B. Water status, leaf area and fruit load influence on berry weight and sugar accumulation of $\mathrm{cv}$. 'Tempranillo' under semiarid conditions. Scientia Horticulturae, v.109, p.60-65, 2006.

SINGLETON, V.L.; ROSSI JUNIOR, A. Colorimetry of total phenolics with phosphomolybdic-phosphotungstic acid reagent. American Journal of Enology and Viticulture, v.16, p.144-158, 1965.

STATSOFT. Statistica for Windows. Version 6. Tulsa: Statsoft, 2001.

TONIETTO, J.; CARBONNEAU, A. A multicriteria climatic classification system for grape-growing regions worldwide. Agricultural and Forest Meteorology, v.124, p.81-97, 2004.

WINKLER, A.J. Viticultura. México: Compañia Editorial Continental, 1980. 792p.

WOLPERT, J.A.; KASIMATIS, A.N.; VERDEGAAL, P.S. Viticultural performance of seven Cabernet Sauvignon clones in the Northern San Joaquin Valley, California. American Journal of Enology and Viticulture, v.46, p.437-441, 1995.

ZAMUZ, S.; MARTÍNEZ, M.C.; VILANOVA, M. Primary study of enological variability of wines from different clones of Vitis vinifera L. cv. Albariño grown in Misión Biológica de Galicia (CSIC). Journal of Food Composition and Analysis, v.20, p.591-595, 2007.

Received on March 15, 2011 and accepted on April 15, 2011 